\title{
Modern Data on the Bronze Age Radiocarbon Chronology in the Minusinsk Basins
}

\author{
A. V.Poliakov, S. Svyatko
}

For citation: Poliakov A. V., Svyatko S. Modern Data on the Bronze Age Radiocarbon Chronology in the Minusinsk Basins. Vestnik of Saint Petersburg University. History, 2021, vol. 66, issue 3, pp. 934-949. https://doi.org/10.21638/11701/spbu02.2021.314

In 2009, the first radiocarbon chronology of the Bronze Age and Scythian period of the Minusinsk Basins was published, which laid foundation for a system analysis of further results. Over the past decade, the total number of radiocarbon definitions has further increased by almost a quarter. The most important changes have affected the chronological frames of Afanasyeva Culture. A vast series of new AMS dates obtained from the Altai Mountains sites showed that a significant number of the earlier age estimates erroneously suggested the sites to be considerably older. This phenomenon probably affected the Minusinsk Basins as well. The new dates shifted the boundaries of the Afanasyeva Culture in the Middle Yenisei Region to the $30^{\text {th }}-25^{\text {th }} \mathrm{c}$. BC, and the timing of the earliest Okunev Culture burials to the end of the $26^{\text {th }} \mathrm{c}$. BC rather than the beginning of the $25^{\text {th }} \mathrm{c}$. BC. This suggests a 100 -year period of coexistence of the Afanasyeva and Okunev Cultures. Moreover, the new dates filled the "hiatus" between the end of the Okunev and beginning of the Andronovo Culture, discussed in 2009. The end of the Okunev can now be attributed to the $17^{\text {th }} \mathrm{c}$. BC. The new dates fully confirm the narrow chronology of the Andronovo (Fedorov) Culture on the Middle Yenisei $-17^{\text {th }}-15^{\text {th }} \mathrm{c}$. BC. Minor changes are seen at the beginning of the Late Bronze Age in the Minusinsk Basins, previously called the Karasuk Culture. The new determinations suggest the end of the $15^{\text {th }} \mathrm{c}$. $\mathrm{BC}$ as the beginning of this period, which is somewhat older than previously thought. The end of the Bronze Age is still dated to the end of the $9^{\text {th }} \mathrm{c}$. BC.

Keywords: Minusinsk Basins, Bronze Age, radiocarbon chronology, Afanasyeva Culture, Okunev Culture, Andronovo (Fedorov) Culture, Late Bronze Age.

Andrei V.Poliakov - PhD (History), Senior Research Fellow, Institute of the History of Material Culture, Russian Academy of Sciences, 18, Dvortsovaya nab., St. Petersburg, 191186, Russian Federation; poliakov@yandex.ru

Андрей Владимирович Поляков - канд. ист. наук, ст. науч. сотр., Институт истории материальной культуры Российской Академии наук, Российская Федерация, 191186, Санкт-Петербург, Дворцовая наб., 18; poliakov@yandex.ru

Svetlana Svyatko - PhD, Research Fellow, 14CHRONO Centre for Climate, the Environment and Chronology, Queen's University Belfast, University Road, Belfast, Northern Ireland, BT7 1NN, United Kingdom; svetlana_sv@mail.ru

Светлана Святко - PhD, науч. сотр., Центр 14CHRONO по климату, окружающей среде и хронологии, Королевский университет Белфаста, Великобритания, BT7 1NN, Белфаст, Юниверсити-роуд; svetlana_sv@mail.ru

The study was carried out within the framework of the Basic Scientific Research of the State Academies of Sciences, state assignment No. 0160-2020-0002 "The ancient history of the Sayan-Altai uplands from the Bronze Age to the Middle Ages: chronology and cross-cultural interaction”.

Исследование выполнено в рамках темы государственного задания ФНИ ГАН № 0160-20200002 «Древняя история Саяно-Алтайского нагорья от эпохи бронзы до Средневековья: хронология и кросс-культурное взаимодействие».

(C) St. Petersburg State University, 2021 


\section{Современные данные по радиоуглеродной хронологии эпохи бронзы Минусинских котловин}

\section{А. В. Поляков, С. Святко}

Для цитирования: Poliakov A. V., Svyatko S. Modern Data on the Bronze Age Radiocarbon Chronology in the Minusinsk Basins // Вестник Санкт-Петербургского университета. История. 2021. T.66. Вып. 3. С. 934-949. https://doi.org/10.21638/11701/spbu02.2021.314

В 2009 г. в серии публикаций были подведены итоги изучения радиоуглеродной хронологии памятников эпохи бронзы и скифского времени Минусинских котловин и заложена основа дальнейшего системного анализа результатов. За прошедшее десятилетие проведено большое количество новых радиоуглеродных измерений, увеличивших число дат почти на четверть. Наиболее важные изменения произошли в отношении хронологических границ афанасьевской культуры. Большая серия новых дат по образцам из памятников Горного Алтая, выполненных с применением ускорительной методики, позволила установить, что значительная часть ранее сделанных определений неверно определяла возраст памятников, значительно их удревняя. Эта тенденция, вероятно, коснулась и Минусинских котловин. С учетом новых определений рамки афанасьевской культуры на Среднем Енисее определены в пределах XXX-XXV вв. до н. э. По новым данным наиболее ранние захоронения окуневской культуры датируются финалом XXVI в. до н. э., а не началом XXV в. до н.э., как считалось прежде. Это позволяет рассматривать период сосуществования афанасьевской и окуневской культур на протяжении около 100 лет. Кроме того, новыми датами заполнился хиатус между финалом окуневской и началом андроновской культуры, который был отмечен в публикациях 2009 г. На основании современных результатов финал окуневской культуры теперь следует относить к XVII в. до н. э. Новая серия радиоуглеродных дат полностью подтвердила узкие хронологические рамки андроновской (федоровской) культуры на Среднем Енисее, которые укладываются в период XVII-XV вв. до н.э. Небольшие изменения произошли в отношении начала периода поздней бронзы Минусинских котловин, ранее называвшегося карасукской культурой. Новые определения дают основания считать, что начало этого периода может относиться к финалу XV в. до н. э., что несколько древнее, чем предполагалось ранее. Дата финала эпохи бронзы по-прежнему относится к концу IX в. до н.э.

Ключевые слова: Минусинские котловины, эпоха бронзы, радиоуглеродная хронология, афанасьевская культура, окуневская культура, андроновская (федоровская) культура, поздняя бронза.

The research into the radiocarbon $\left({ }^{14} \mathrm{C}\right)$ dating of the Bronze Age archaeological sites of the Minusinsk Basins started at the very beginning of the development of the method itself. Since 1956, on the basis of the V.G. Khlopin Radium Institute and the Leningrad Branch of the Institute of Archaeology of the Academy of Sciences of the Soviet Union, the country's first radiocarbon laboratory began to operate in Leningrad ${ }^{1}$. This method caught the attention of M.P.Gryaznov, and some of the first samples were brought from the sites explored by the Krasnoyarsk expedition in the Minusinsk Basins. These were mostly burials of the Afanasyeva and Andronovo Cultures. The first results were very contradictory, which abruptly reduced further interest in this method. However, with the efforts of such enthusiasts as, for example, E. B. Vadetskaia and N. A. Bokovenko, the source

${ }^{1}$ Zaitseva G. I., Timofeev V.I., Sementsov A.A. Radiouglerodnoe datirovanie v IIMK RAN: istoriia, sostoianie, rezul'taty, perspektivy // Rossiiskaia arkheologiia. 1999. No. 3. P. 5-21. 
base was constantly replenished, the new results were introduced into scientific discourse and used to determine the age of archaeological sites and entire cultures. Of particular importance was a series of ${ }^{14} \mathrm{C}$ dates obtained by a group of German researchers (A.Nagler and G. Parzinger), who, together with local archaeologists (A. I. Gotlib, V.S.Zubkov, A.I.Poselianin, K. G. Kotozhekov), investigated the sites around the Sukhanikha Mountain (mouth of the Tuba River). They attempted to build an independent radiocarbon chronology based only on the sites researched by their group ${ }^{2}$.

In 2009, a series of publications on the ${ }^{14} \mathrm{C}$ dating issues of the Minusinsk Basins sites appeared in Russian and foreign scholarship ${ }^{3}$. Not only they introduced 88 new dates, but also critically analyzed all previous age definitions of the Bronze Age and Scythian time sites in the area. This study stands out for several fundamental points: firstly, for a rigorous critical approach to the sources, which allowed detecting a significant number of admittedly arguable ${ }^{14} \mathrm{C}$ dates; secondly, for the use of all previously obtained reliable dates and applying the uniform calibration procedure to them; thirdly, for the use of the OxCal statistical algorithms for summarizing these dates. As a result, the most complete and concise picture of the proportion of ${ }^{14} \mathrm{C}$ dates for various archaeological cultures was made.

Further ${ }^{14} \mathrm{C}$ research into the chronology of the prehistoric sites of the Minusinsk Basins explored in depth data on individual archaeological cultures: Afanasyeva ${ }^{4}, \mathrm{Okunev}^{5}$ and Andronovo ${ }^{6}$. Special attention, both in Russian and foreign literature, was given to the problems of unreliable dates for the Afanasyeva Culture sites in the Altai ${ }^{7}$. Other publications discussed ${ }^{14} \mathrm{C}$ data on the Minusinsk Basins and neighbouring regions ${ }^{8}$. At the same time, the accumulation of new dates continued. For example, for the Okunev Culture, the number of known age determinations went up almost two-and-a-half times in the last ten years. Thus, the extent of the new knowledge over the past period has reached a certain milestone, and it now requires the formation of a new single concept of ${ }^{14} \mathrm{C}$ chronological

${ }^{2}$ Görsdorf J., Parzinger H., Nagler A, Leontyev N. Neue ${ }^{14}$ C-Datierungen für die Sibirische Steppe und ihre Konsequenzen für die regionale Bronzezeitchronologie // Eurasia Antiqua. Berlin. 1998. Bd. 4. S.73-80; Görsdorf J., Parzinger H., Nagler A. New radiocarbon dates of the North Asian steppe zone and its consequences for the chronology // Radiocarbon. 2001. Vol. 43 (2B). P. 1115-1120.

${ }^{3}$ Svyatko S. V., Mallory J.P., Murphy E. M. et al. New radiocarbon dates and a review of the chronology of prehistoric populations from the Minusinsk basin, Southern Siberia, Russia // Radiocarbon. 2009. Vol. 51 (1). P. 243-273; Poliakov A. V., Svyatko S. V. Radiouglerodnoe datirovanie arkheologicheskikh pamiatnikov neolita - nachala zheleznogo veka Srednego Eniseia: obzor rezul'tatov i novye dannye // Teoriia i praktika arkheologicheskikh issledovanii. 2009. Vyp.5. P.20-56; Svyatko S. V., Poliakov A. V. Novye radiouglerodnye daty pamiatnikov epokhi bronzy - nachala zheleznogo veka Srednego Eniseia // Rol' estestvenno-nauchnykh metodov v arkheologicheskikh issledovaniiakh. Barnaul, 2009. P. 146-149.

${ }^{4}$ Poliakov A. V. Radiouglerodnye daty afanas'evskoi kul'tury // Afanas'evskii sbornik. Barnaul, 2010. P. 158-171.

${ }^{5}$ Poliakov A. V. Radiouglerodnye daty okunevskoi kul'tury // Zapiski IIMK RAN. 2017. No. 16. P. 52-74.

${ }^{6}$ Poliakov A. V. Radiouglerodnye daty pamiatnikov andronovskoi (fedorovskoi) kul'tury na Srednem Enisee // Zapiski IIMK RAN. 2019. No. 20. P.163-173.

7 Poliakov A. V., Svyatko S. V., Stepanova N.F. Novye dannye po radiouglerodnoi khronologii pamiatnikov afanas'evskoi kul'tury Altaia // Trudy V (XXI) Vserossiiskogo arkheologicheskogo s"ezda v Barnaule-Belokurikhe. T.III. Barnaul. 2017. P.62-66; Poliakov A., Svyatko S., Stepanova N.: 1) A review of the radiocarbon dates for the Afanasyevo Culture (Central Asia): Shifting towards the "shorter" chronology // Radiocarbon. 2019. Vol.61, iss. 1. P.243-263; 2) Problema radiouglerodnoi khronologii afanas'evskoi kul'tury i novye dannye. Fenomeny kul'tur rannego bronzovogo veka stepnoi i lesostepnoi polosy Evrazii: puti kul'turnogo vzaimodeistviia v V-III tyc. do n. e. Orenburg, 2019. P. 181-187.

8 Poliakov A. V., Svyatko S. V., Stepanova N. F. Sovremennoe sostoianie radiouglerodnogo datirovaniia afanas'evskoi i okunevskoi kul'tur // Nauchnoe obozrenie Saiano-Altaia. 2018. No. 1 (21). Vyp. 5. P. 14-22. 


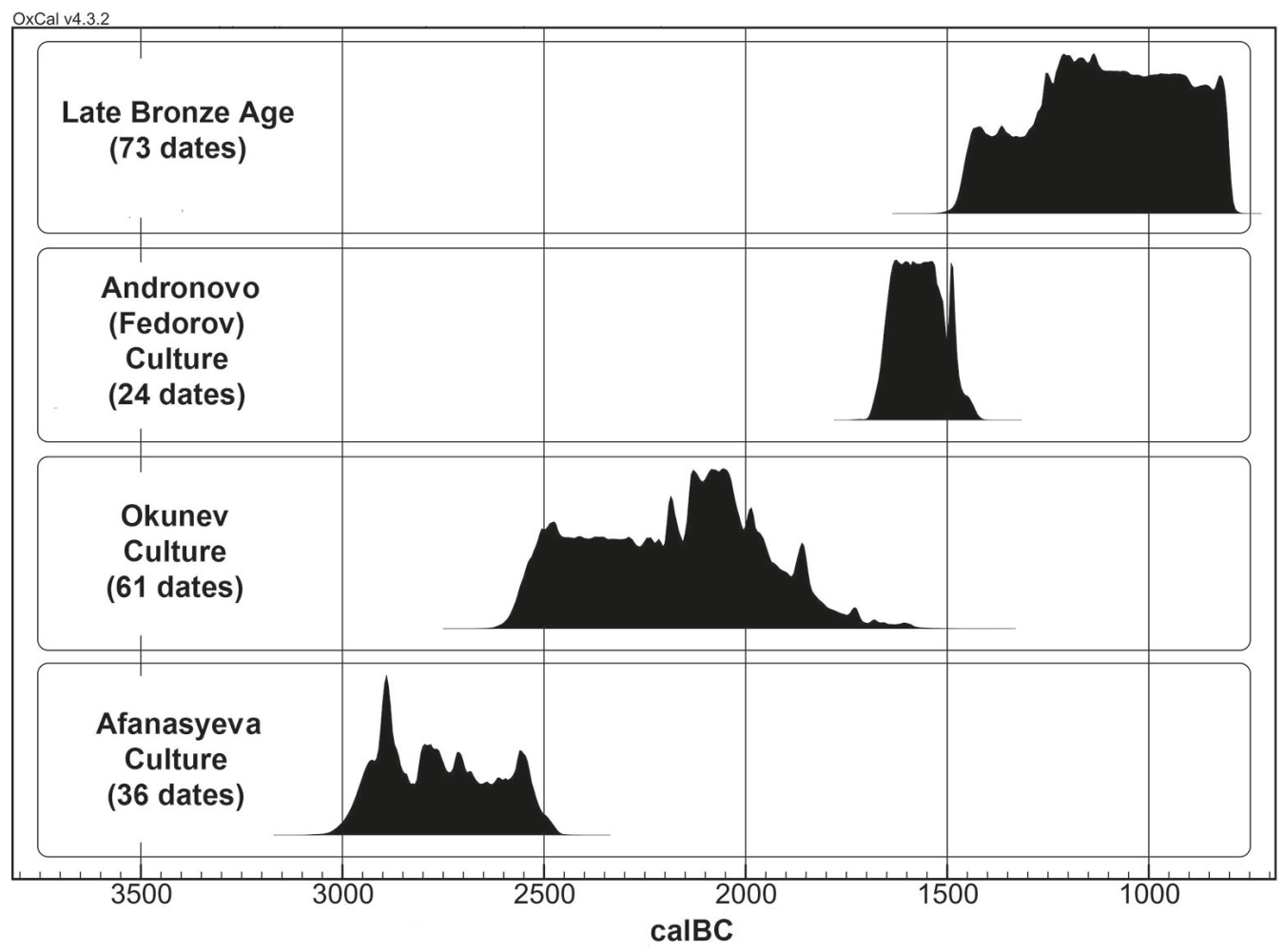

Fig. 1. Comparison of summed probabilities of calibrated ${ }^{14} \mathrm{C}$ dates for the Bronze Age archaeological Cultures of the Minusinsk Basins (Sum and Boundary functions used)

column. In this article, we make an attempt to summarise the data on a new higher level (Fig. 1).

Unfortunately, over the past decade, there have been no reliable ${ }^{14} \mathrm{C}$ dates for the Neolithic samples. This is directly related to the fact that so far no burial complexes of this period have been found in the Minusinsk Basins. Only a small number of camps are known, and the layers are overlaid and mixed with those of the later Afanasyeva and Okunev Cultures ${ }^{9}$. All isolated burials, which were previously attributed to this period, have been confidently dated to the Okunev Culture. Thus, there are no grounds for developing the chronology of this period in the Minusinsk Basins.

The earliest Bronze Age sites in the region are represented by the Afanasyeva Culture ${ }^{10}$. In the 2009-2010 publications, they were dated to the $37^{\text {th }}-25^{\text {th }} \mathrm{c}$. BC ${ }^{11}$. Even at that time it was already clear that such a long 1400-year period of existence of the culture did not agree with archaeological realities. The number of cemeteries and burials within them is relatively small and would not be sufficient to fill such a long chronological interval. The detailed study of these materials did not reveal any internal chronological stages, which

9 Vadetskaia E. B. Arkheologicheskie pamiatniki v stepiakh Srednego Eniseia. Leningrad, 1986.

10 Vadetskaia E. B., Poliakov A. V., Stepanova N. F. Svod pamiatnikov afanas'evskoi kul'tury. Barnaul, 2014.

11 Poliakov A. V. Radiouglerodnye daty afanas'evskoi kul'tury. 


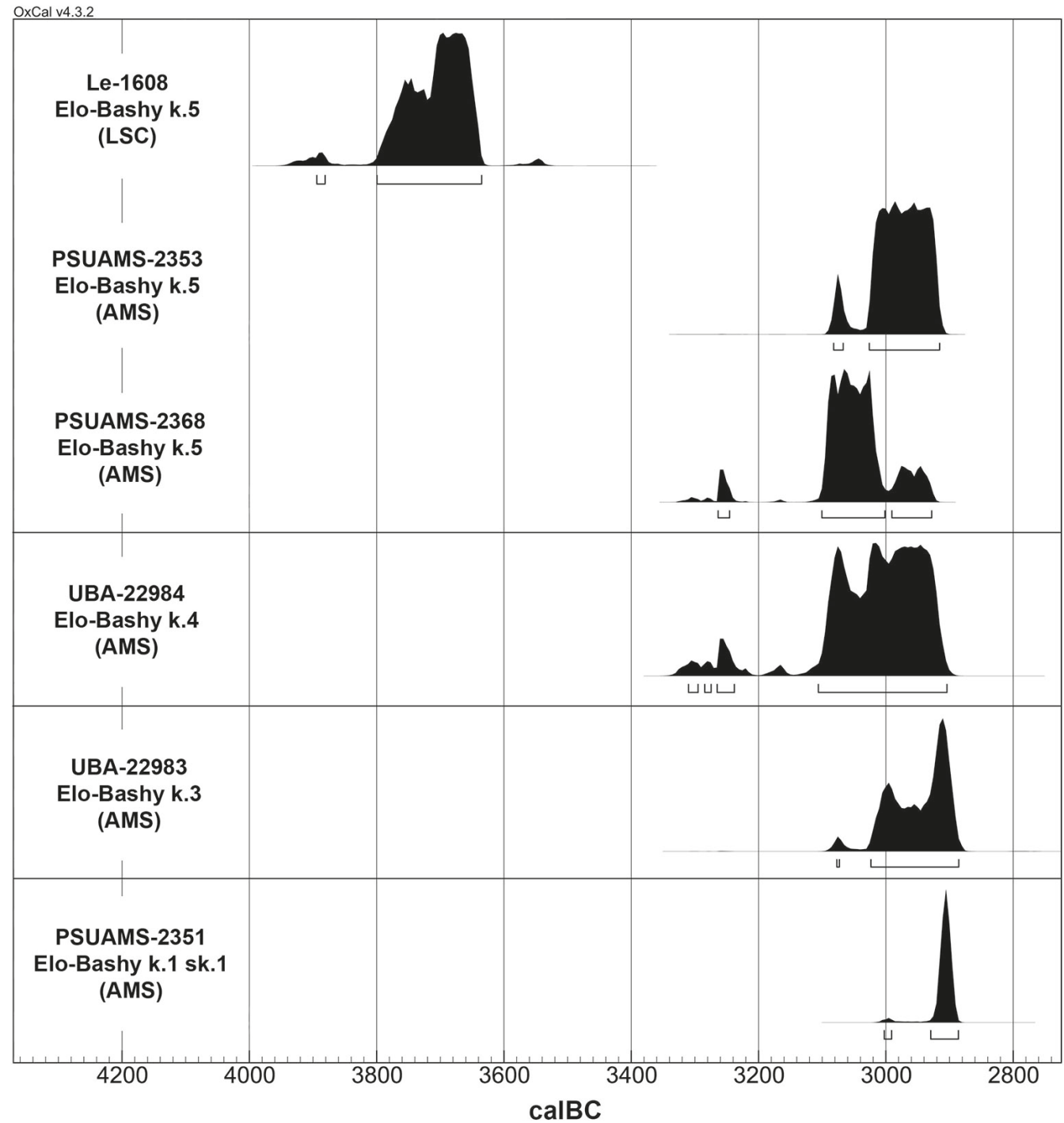

Fig. 2. Comparison of the ${ }^{14} \mathrm{C}$ dates from the Elo-Bashi cemetery (Afanasyeva Culture of Altai)

is very surprising if we admit the 1400-year existence of the culture. Finally, there were numerous paradoxes associated with the Yamnaya Culture. The earliest Afanasyeva sites appeared older than Yamnaya; this introduced a contradiction into the concept of their origin, based on the eastward migration of the Yamnaya population. Although there was an understanding of the ambiguity of this situation, there was no reason for distrusting the existing ${ }^{14} \mathrm{C}$ dates. As a result, a broad framework of the Afanasyeva Culture $\left(37^{\text {th }}-25^{\text {th }} \mathrm{c}\right.$. $\mathrm{BC})$ was entrenched in the scientific literature.

A crucial change in this situation occurred in 2017, when a number of the Afanasyeva Culture sites in the Altai, which had previously been considered as the oldest known, were re-dated. The vast majority of the new dates appeared $600-700$ years younger than those received earlier (Fig. 2). 


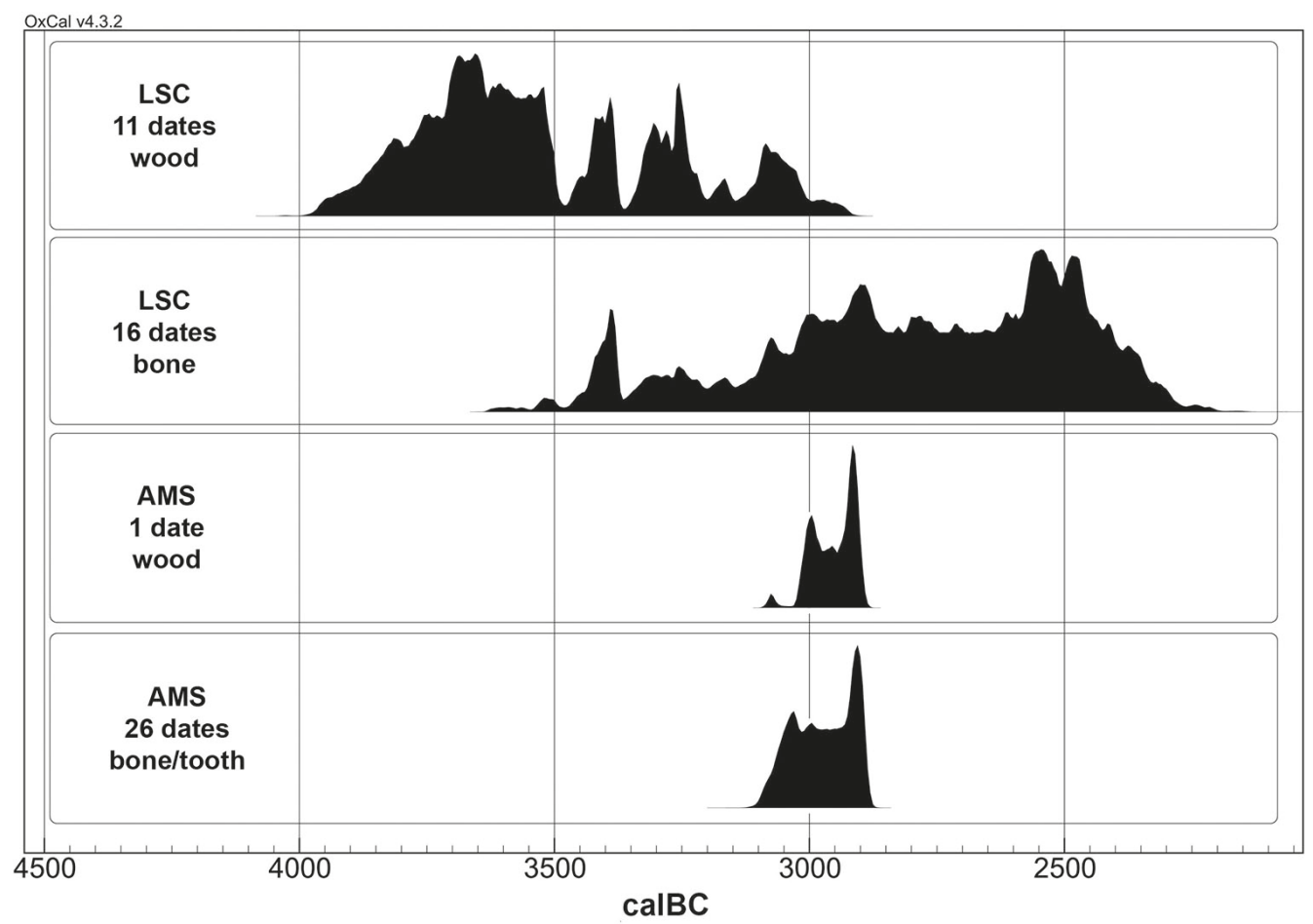

Fig. 3. Comparison of summed probabilities of calibrated ${ }^{14} \mathrm{C}$ dates for the Afanasyeva Culture of Altai, made using various methods on wood and bone samples (Sum and Boundary functions used)

Furthermore, all samples dated with modern accelerator mass spectrometry (AMS) technique fell into a very narrow chronological period not exceeding 300 years. The dates received later, in 2018-2019, fully agreed with the 2017 dates $^{12}$. So far, 27 AMS dates for the Afanasyeva Culture in the Altai have been published, and all of them belong to the $31^{\text {th }}-29^{\text {th }}$ c. BC. On this basis, the concept of the "short" chronology of the Afanasyeva Culture was proposed as a result of the rejection of the previous determinations and the use of exclusively modern measurements ${ }^{13}$.

The causes of this phenomenon are yet to be explained. All previous measurements were made in the laboratories of Novosibirsk (SOAN) and St. Petersburg (Le) following the conventional liquid-scintillation technique (LSC). At the same time, only those received from wood samples (Fig. 3) were unreasonably old.

Dates from human bone collagen, on the contrary, appeared slightly too young. The reasons for the latter could be that they were not amended for the isotopic fractionation, which is essential in modern AMS laboratories. However, it appears that the problem with the determinations of questionable age was not only related to the sample material. The results of re-dating of the wood sample from the ceiling of the Kara-Koba 1 cemetery grave 3 (UBA-35116) using AMS technique, were also 600 years younger than previous determinations (Fig. 2). Thus, in order to obtain the reliable dates for the Afanasyeva sites

\footnotetext{
12 Poliakov A. V., Svyatko S. V., Stepanova N. F. Problema radiouglerodnoi khronologii...

13 Poliakov A., Svyatko S., Stepanova N. A review of the radiocarbon dates...
} 


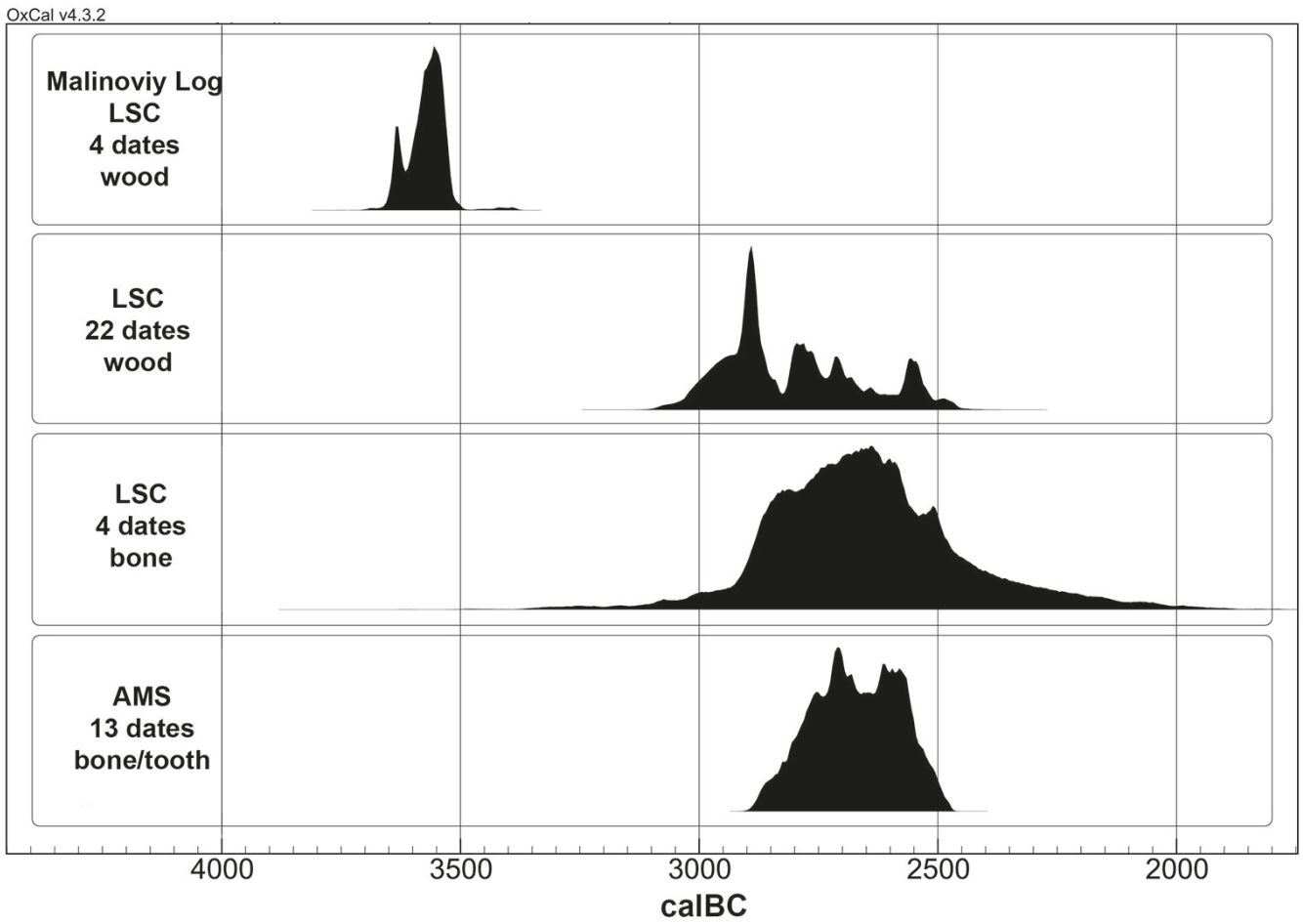

Fig. 4. Comparison of summed probabilities of calibrated ${ }^{14} \mathrm{C}$ dates for the Malinoviy Log cemetery and other sites of the Afanasyeva Culture of the Minusinsk Basins, made using various methods on various samples (Sum and Boundary functions used)

of Altai and to determine their age, it appears feasible to use only modern measurements, especially since their number has already exceeded the number of previously made measurements.

This problem partly concerns the Minusinsk Basins as well. We have previously questioned the reliability of the four dates from Malinoviy $\log ^{14}$ - these are 600 years older than all other dates from the Afanasyeva sites of the Minusinsk Basins (Fig. 4).

Given the revealed problem with the Altai dates, we can suggest that in this case we are also dealing with this so far poorly understood effect. Interestingly, the rest of age determinations for the Middle Yenisei sites, made using the conventional (LSC) method on wood samples, do not show any differences from modern dates. We assume that the effect, visible on almost all wood samples from Altai, appears only sporadically in the Minusinsk Basins.

Another important observation of this research was the lack of synchronicity of the Afanasyeva Culture sites in different regions. Comparison of modern (AMS) radiocarbon dates shows that all analysed Altai sites are older than those of the Minusinsk Basins (Fig. 5).

${ }^{14}$ Bokovenko N.A., Mitiaev P.E. Afanas'evskii mogil'nik Malinovyi Log na Enisee // Afanas'evskii sbornik. Barnaul, 2010. P. 16-29. 


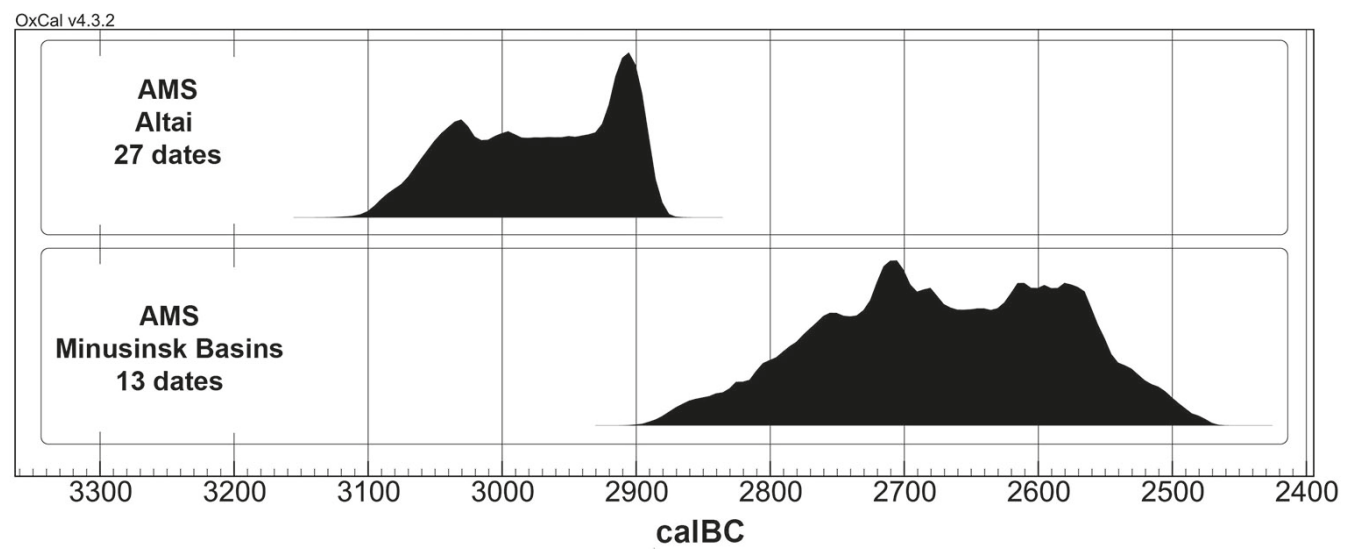

Fig. 5. Comparison of summed probabilities of calibrated AMS ${ }^{14} \mathrm{C}$ dates for the Afanasyeva Culture sites in the Altai and the Minusinsk Basins (Sum and Boundary functions used)

Notably, the latest research carried out with traditional archaeological methods draws similar conclusions. According to I. P. Lazaretov, the earliest Afanasyeva burial complexes in the Minusinsk Basins are the most similar to the Altai materials, while the later ones have a distinct originality ${ }^{15}$. This does not mean that the Afanasyeva tradition was completely interrupted in the Altai in the $29^{\text {th }} \mathrm{c}$. BC. To date, these sites include several specific groups of burials (Kurota, Ulita, Aragol types), which have not been AMS ${ }^{14} \mathrm{C}$ dated ${ }^{16}$. Perhaps, they will chronologically fall into the period between the Afanasyeva materials themselves and those of the subsequent Karakol Culture.

As such, at the moment the chronology of the Afanasyeva Culture in the Middle Yenisei Region should be established on the basis of $36{ }^{14} \mathrm{C}$ dates, which do not include those from the Malinoviy Log cemetery. The combined analysis demonstrates the development of the culture for about 500 years, between $30^{\text {th }}-25^{\text {th }}$ c. BC (Fig. 1). This approach completely removes all contradictions associated with the Yamnaya Cultural-Historical Horizon, which appears several hundred years older. Recent research in physical anthropology ${ }^{17}$ and genomics ${ }^{18}$ leaves no more doubts on the relationship between the two populations. The formation of the Afanasyeva Culture appears to be the result of the eastward migration of a part of the Yamnaya population and their spread in entirely new territories inhabited at that time by autochthonous Neolithic tribes.

The question of the transition from the Afanasyeva to Okunev Culture requires detailed attention. The issue was virtually avoided in the 2009 publications. Due to the small number of dates, the beginning of the Okunev Culture was dated to the $25^{\text {th }} \mathrm{c}$. BC. Yet, an extensive study of the early Uibat stage carried out by Saint-Petersburg researchers, allowed to significantly increase the number of age determinations of the earliest mounds

${ }^{15}$ Lazaretov I.P. K otnositel'noi khronologii afanas'evskoi kul'tury Srednego Eniseia ili khorosho zabytoe staroe // Drevnosti Sibiri i Tsentral'noi Azii. 2017. No. 8 (20). P. 8-34.

16 Vadetskaia E. B., Poliakov A. V., Stepanova N. F. Svod pamiatnikov afanas'evskoi kul'tury.

17 Khokhlov A. A., Solodovnikov K. N., Rykun M. P. et al. Kraniologicheskie dannye k probleme sviazi populiatsii iamnoi i afanas'evskoi kul'tur Evrazii nachal'nogo etapa bronzovogo veka // Vestnik arkheologii, antropologii i etnografii. 2016. No. 3 (34). P. 86-106.

18 Allentoft M.E., Sikora M., Sjögren K. G. et al. Population genomics of Bronse Age Eurasia // Nature. 2015. Vol.522, no. 7555. P. 167-172. 
of this period. As a result, it became clear that the formation of the Okunev Culture should be dated to the second half of the $26^{\text {th }} \mathrm{c}$. BC, which suggests that there was a short period of coexistence between the Afanasyeva and Okunev Cultures. It is difficult to establish the exact chronology of this period, but it can be argued that it dates to the turn of the $26^{\text {th }}$ $25^{\text {th }} \mathrm{c}$. BC and does not exceed 100 years. The evidence for contacts is most obvious in the sites of the final stage of the Afanasyeva Culture in the use of certain funeral traditions, more characteristic of the following culture.

To date, there are $61{ }^{14} \mathrm{C}$ dates for the sites of the Okunev Culture. Over the past 10 years, their number has increased more than twice (from 28). It should be specifically mentioned that all these dates lack problems associated with the Afanasyeva sites in the Altai. This is due to the fact that the radiocarbon dating of samples from Okunev objects began very late, slightly more than 20 years ago. All these dates can be confidently considered modern; the vast majority of them (about $75 \%$ ) were made using AMS. Based on their summed analysis, the Okunev Culture should be considered to have lasted for $800-850$ years and dated to the end of the $26^{\text {th }}-18^{\text {th }}$ c. BC (Fig. 1).

The 2009 publications mentioned two major problems related to the dates of this period. Firstly, at that time it was not possible to support with ${ }^{14} \mathrm{C}$ dating the already accepted division of the Okunev Culture into the chronological stages: Uibat and Chernov ${ }^{19}$. The picture appeared very puzzling, with almost completely synchronous periods. Relatively recent further special study resolved this problem. The main reason for the unclear chronology was that at the initial stage, the samples for the ${ }^{14} \mathrm{C}$ research into Okunev Culture were mostly collected from disturbed complexes. As modern studies show, the tradition of later penetration into the graves of their ancestors for the purpose of subsequent burial or relocation of the remains was very characteristic of the Okunev Culture ${ }^{20}$. As a result, a significant number of first dates on the Uibat stage graves dated not to the very moment of the main burial, but to further, much later activity. The appreciation of this problem prompted re-analysing the sources and filtering out the controversial dates. In addition, a significant series of new dates was acquired, exclusively from closed complexes without traces of later disturbance.

The analysis of these reliable dates revealed a very clear picture which confirmed the already established division of the Okunev sites into chronological stages (Fig. 6).

This allowed not only supporting the validity of the established relative chronology, but also determining the boundaries of chronological stages in absolute dates. The earliest Uibat stage can be attributed to the end of the $26^{\text {th }}-23^{\text {rd }} c$. BC. The next chronological period, the Chernov stage, is dated to the $22^{\text {nd }}-20^{\text {th }} \mathrm{c}$. BC. Finally, the end of the Okunev Culture, named by D. G. Savinov the Razlivskiy stage ${ }^{21}$, already has two reliable dates and is attributed to the $19^{\text {th }}-18^{\text {th }} \mathrm{c}$. BC. Thus, the concept of the relative chronology of the Okunev Culture has gained strong support having been confirmed by the natural science method.

${ }^{19}$ Lazaretov I.P. Okunevskie mogil'niki v doline reki Uibat // Okunevskii sbornik. St. Petersburg, 1997. P. 19-64.

${ }^{20}$ Lazaretov I.P., Morozov S. V., Poliakov A. V. Novye dannye o manipuliatsiiakh s cherepami v pogrebal'nom obriade okunevskoi kul'tury // Drevnie nekropoli - pogrebal'no-pominal'naia obriadnost', pogrebal'naia arkhitektura i planirovka nekropolei. St. Petersburg, 2018. P. 51-56.

${ }^{21}$ Savinov D. G. K probleme vydeleniia pozdnego etapa okunevskoi kul'tury // Teoriia i praktika arkheologicheskikh issledovanii. 2005. Vyp. 1. P.28-34. 


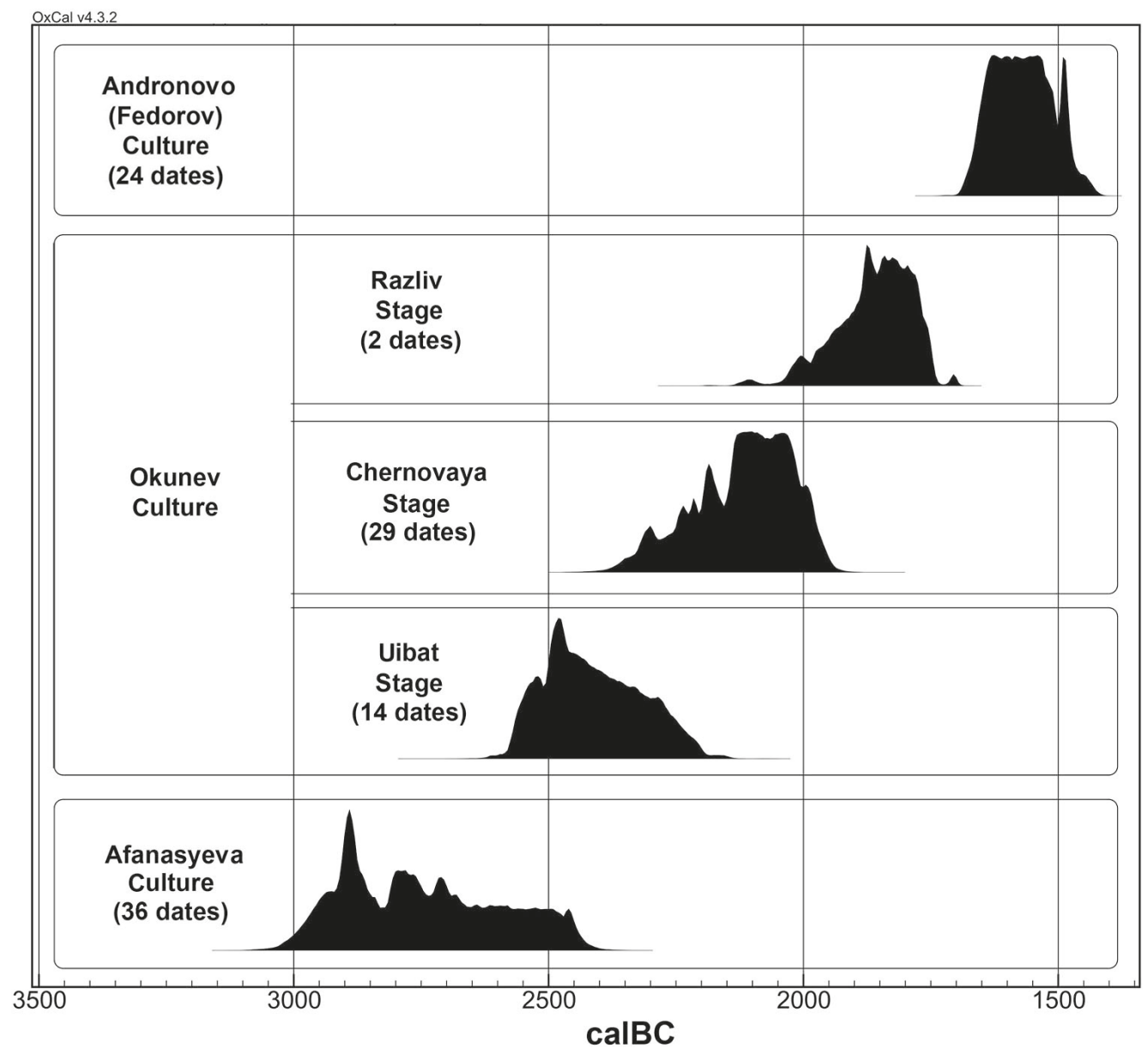

Fig. 6. Comparison of summed probabilities of calibrated ${ }^{14} \mathrm{C}$ dates for the Okunev Culture stages in the Minusinsk Basins (Sum and Boundary functions used)

Another issue raised previously is the existence of the nearly 150 year "hiatus" between the dates of the Okunev and Andronovo Cultures. In 2009, it was already mentioned that this was due to the insufficient number of ${ }^{14} \mathrm{C}$ measurements. Indeed, over the past ten years it has become clear that this was a purely technical problem related to the lack of dates for the latest Okunev sites. Only three mounds which can be attributed to this still understudied period are known, and only two dates have been received for them, but these confidently fall into the previously found "hiatus", bordering with the dates of the following Andronovo Culture (Fig. 6). Unfortunately, this does not appear as final solution to the problem related to the end of the Okunev Culture. Taking into account the limited localization of the Andronovo sites in the territory of the Minusinsk Basins (only in the north), leading experts suggest that the population of the Okunev Culture could have continued living in the southern areas for a long time. However, we do not yet know specific Okunev complexes that could be synchronized with the Andronovo Culture on the Yenisei. Their discovery and study are one of the vital aims of modern archaeology of the Minusinsk Basins. 
The new period in the prehistory of the Minusinsk Basins is concerned with the invasion of the Andronovo (Fedorov) Culture tribes. The first age determinations for these sites were the large series of unreliable dates with a spread of up to 3000 years, which caused a long-standing distrust of many Russian researchers in the potential of the ${ }^{14} \mathrm{C}$ dating. In 2009 publications, it was noted that modern measurements were not affected by this problem, and if we excluded all dates received before 1990, we could get a clear chronological interval between the $17^{\text {th }}-15^{\text {th }} \mathrm{c}$. BC. The main difficulty was the small number of determinations available at that time (only 14).

Over the past 10 years, only ten new radiocarbon dates have been added for the Andronovo (Fedorov) sites of the Minusinsk Basins. These were received as a part of the latest paleogenetic research by a large international team ${ }^{22}$. The definitions fully fall within the previously specified chronological period of $17^{\text {th }}-15^{\text {th }} \mathrm{c}$. BC and confirm the reliability of the previous approach. Thus, it has become even clearer that the presence of the Andronovo population in the Middle Yenisei lasted for no more than 300 years.

Finally, the end of the Bronze Age in the Middle Yenisei Region is associated with sites that have traditionally been united under the concept of the "Karasuk Culture". Modern research demonstrates the existence of a large number of different cultural impulses during this period, which makes it impossible to consider these diverse complexes as belonging to the same culture ${ }^{23}$. Analysis of this period allows differentiating four chronological stages, combining eight individual horizons. For the past 10 years, the number of ${ }^{14} \mathrm{C}$ determinations for these sites has barely increased. Only a few dates were added as a part of the genomic research, and the total number of definitions reached 73 . The plotted data demonstrates the amazing homogeneity of the whole series. The chronological boundaries of the Late Bronze Age are clearly defined as the end of the $15^{\text {th }}-9^{\text {th }} \mathrm{c}$. BC (Fig. 1). The upper limit completely agrees with the archaeological data, and the lower one appears one century older. According to latest research, analogies to objects of the $13^{\text {th }} \mathrm{c}$. BC from Northern China are found only in the burials of the second stage of the Late Bronze Age, according to the chronology by A. V. Poliakov and I. P. Lazaretov, while the earlier sites of the first stage may well date back to the $14^{\text {th }} \mathrm{c}$. $\mathrm{BC}^{24}$. If we bear this in mind, the archaeological and radiocarbon data on the chronology of the Late Bronze Age correspond completely.

In 2009, when the first summarising analysis of the dates for this period was carried out, an attempt was made to split the dates, according to the chronology of M.P. Gryaznov, into those of the "classic" and Kamenniy Log stages. The summed probability of the first group appeared within the $14^{\text {th }}-11^{\text {th }} c$. BC, and of the second - within the $13^{\text {th }}-9^{\text {th }} c$. $\mathrm{BC}^{25}$. At the same time, it was pointed out that the issue was mainly related to the measurements from the Kamenniy Log stage cemetery of Sukhanikha. It was ten dates from this site that made the lower limit of the later stage of the Karasuk Culture significantly older. If these dates are excluded from the analysis, the timing of the Kamenniy Log stage

${ }^{22}$ Narasimhan V., Patterson N., Moorjani P. et al. The Genomic Formation of South and Central Asia // Science. 2019. Vol.365. P. eaat7487-eaat7487.

${ }^{23}$ Lazaretov I. P., Poliakov A. V. Khronologiia i periodizatsiia kompleksov epokhi pozdnei bronzy Iuzhnoi Sibiri // Etnokul'turnye protsessy v Verkhnem Priob'e i sopredel'nykh regionakh v kontse epokhi bronzy. Barnaul, 2008. P.33-55.

24 Poliakov A.V. Periodizatsiia "klassicheskogo" etapa karasukskoi kul'tury (po materialam pogrebal'nykh pamiatnikov): dis. ... kand. philos. nauk. St. Petersburg, 2006.

${ }_{25}$ Poliakov A. V., Svyatko S. V. Radiouglerodnoe datirovanie arkheologicheskikh pamiatnikov neolita... 
becomes shorter $-11^{\text {th }}-9^{\text {th }} c$. BC, which is quite consistent with modern archaeological concepts. The unexpectedly old age of this group of burials from Sukhanikha drew attention of German researchers themselves at the time of the publication ${ }^{26}$.

The set of dates from Sukhanikha should be considered in more detail. Their closer examination draws attention to two dates (Bln-5281 and Bln-5317) from same burial (Sukhanikha II k. 11 g. 1). Based on the funeral rite, types of structures and accompanying equipment, this grave is dated to the Kamenniy Log stage, according to M. P. Gryaznov, or the third stage of the Late Bronze Age, according to A. V. Polyakov and I. P. Lazaretov. The tests were made in the same laboratory, but on different types of samples (wood and human bone). The calibrated age ranges of these samples show the gap of almost 200 years between each other. The date from the human bone $\left(1^{\text {st }} \mathrm{c}\right.$. BC) fully agrees with traditional views on the timing of such sites (of the Kamenniy Log or the third stage of the Late Bronze Age). Similar dates have been obtained on neighbouring burials, and they also fall within $11^{\text {th }}-9^{\text {th }}$ c. BC (Sukhanikha II k. $11 \mathrm{~A} \mathrm{g.} \mathrm{1,} \mathrm{and} \mathrm{k.} 10$ g. 1). The second date, obtained from wood from the same grave, belongs to the $14^{\text {th }}-13^{\text {th }} \mathrm{c}$. BC, and there is every reason to believe that it is not correct. Now it gets clear that other particularly early dates from the burials of this group are also received from wood samples. It appears possible that the phenomenon could be repetitive. Thus, a series of measurements from the Sukhanikha burial ground made on wood samples appears unreliable. Given that this series raised major issues when the radiocarbon dates were merged with the traditional chronology, we consider it reasonable to avoid using it. If the dates from wood samples are excluded from the series of measurements from Sukhanikha, the picture appears much more realistic. The early group of burials is dated to the $14^{\text {th }}-13^{\text {th }} \mathrm{c}$. BC, the late one - to the $10^{\text {th }}-9^{\text {th }} \mathrm{c}$. BC. A similar situation is emerging when considering another large series of dates from the cemetery of Anchil-Chon ${ }^{27}$. If four dates with excessively wide confidence intervals $\left( \pm 100{ }^{14} \mathrm{C}\right.$ years and more) blurring the details are left out, the chronology of the site becomes much more concise.

With better understanding of the arguable dates, we can interpret the existing data in light of the new, more detailed chronology ${ }^{28}$. Unfortunately, there are still very few dates for the early (I) and late (IV) stages of the Late Bronze Age. Only complexes with reliable relative age were used in the analysis. Ambiguous dates and those with the confidence interval exceeding 100 years were left out, as well as a series of dates from wooden samples from the Sukhanikh I-II burial ground. The resulting pattern is not as bright as the one for the Okunev Culture stages, yet the chronological sequence of the stages can be determined quite confidently (Fig. 7).

The earliest sites of stage I are dated to the late $15^{\text {th }}-13^{\text {th }} \mathrm{c}$. BC. Given the small number of definitions, chronological boundaries of the Andronovo monuments, and the tendencies to inexplicably older dates mentioned earlier, the beginning of the Late Bronze Age of the Minusinsk Basins should still be attributed to the end of the $15^{\text {th }} \mathrm{c}$. BC. The

${ }^{26}$ Görsdorf J., Parzinger H., Nagler A. New radiocarbon dates...

27 Bokovenko N. A., Legrand S. Das karasukzeitliche Gräberfeld Ancil Con in Chakassien // Eurasia Antiqua. Berlin. 2000. Bd. 6. S. 210-248.

28 Poliakov A.V. Skhema periodizatsii klassicheskogo etapa karasukskoi kul'tury. Stepi Evrazii v drevnosti i srednevekov'e. St. Petersburg, 2002. P. 209-213; Poliakov A. V. Periodizatsiia «klassicheskogo» etapa karasukskoi kul'tury (po materialam pogrebal'nykh pamiatnikov); Lazaretov I.P. Zakliuchitel'nyi etap epokhi bronzy na Srednem Enisee: diss. ... kand. philos. nauk. St. Petersburg. 2006; Lazaretov I.P., Poliakov A. V. Khronologiia i periodizatsiia... 


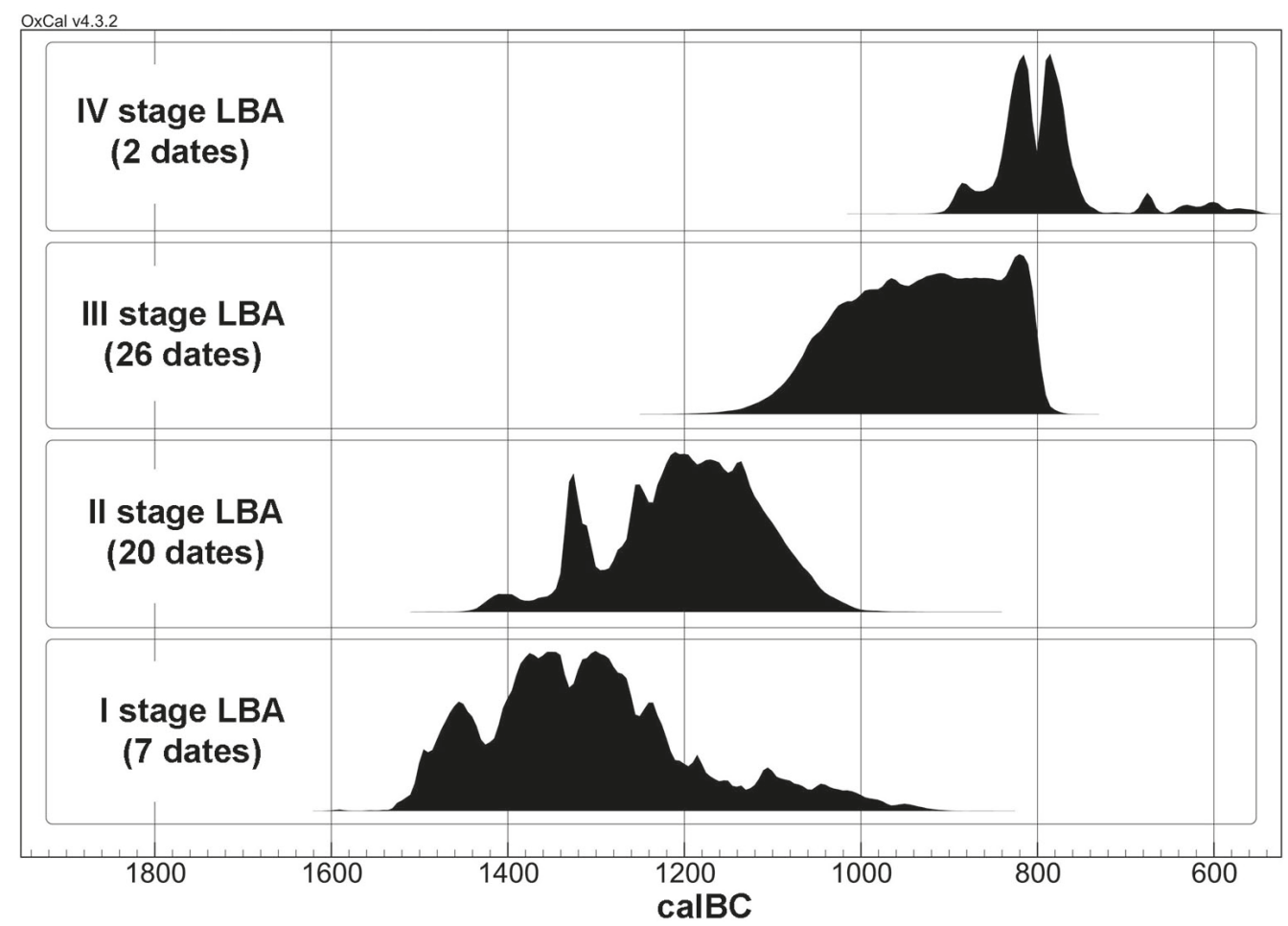

Fig. 7. Comparison of summed probabilities of calibrated ${ }^{14} \mathrm{C}$ dates for the Late Bronze Age stages in the Minusinsk Basins (Sum and Boundary functions used)

boundary between stages I and II is very conditional. It can be confidently assumed that in the north of the Minusinsk Basins the second stage began later than in the south. In general, its boundaries are defined by the $13^{\text {th }}$-beginning of the $11^{\text {th }}$ c. BC. A very clear boundary runs between stages II and III. The latter begins at the end of the $11^{\text {th }} \mathrm{c}$. BC and lasts until the end of the $9^{\text {th }}$ c. BC. Two dates of the "Bainov type" complexes (stage IV) are very compact. They fall on the very interface between the Bronze Age and Scythian time, within the $9^{\text {th }}-8^{\text {th }} \mathrm{c}$. BC. It can be stated that after the critical review of the sources, radiocarbon dates confirm the general trend of composite chronological scheme of the Late Bronze Age in the Minusinsk Basins. Unfortunately, the resolution of the method currently does not allow to consider all eight chronological horizons, but at the level of specific stages the image is quite clear.

A separate complex issue, which we will only outline here, is chronological correlation of sites of the final Bronze Age and Scythian period. Radiocarbon dates of typologically the earliest burials of the Tagar Culture have very wide intervals as a result of falling on the "Hallstatt plateau" on the calibration curve ${ }^{29}$. In some cases, they reach $10^{\text {th }} \mathrm{c}$. BC. Such old age may partly be associated with various effects that have an impact on ${ }^{14} \mathrm{C}$ dates. To verify the long (two century) coexistence of the Bronze Age and early Scythian time sites, an extended ${ }^{14} \mathrm{C}$ study is required, using the equipment that will allow receiving

${ }^{29}$ Alekseev A. Iu., Bokovenko N. A., Vasilev S. S. et al. Evraziia v skifskuiu epokhu. Radiouglerodnaia i arkheologicheskaia khronologiia. St. Petersburg, 2005. 
"narrow" age ranges with low confidence intervals. According to archaeological data, this period was not extensive and most likely dated to the turn of the $9^{\text {th }}-8^{\text {th }} \mathrm{c}$. BC.

Presently, the data on the ${ }^{14} \mathrm{C}$ chronology of the Bronze Age sites in the Minusinsk Basins is still being refined. For the past ten years, since 2009, about 50 new dates have been received, and important improvements have been made in the chronology of the most ancient cultures. The question of the beginning of the Afanasyeva Culture in the Middle Yenisei is of major concern. The rejection of unreasonably old dates from the Malinoviy Log cemetery allows removing a significant number of "problems" and "paradoxes" that arise from comparison with the dates of the Yamnaia Cultural-Historical Horizon. Moreover, the establishment of the older age of the Afanasyeva sites in the Altai is specifically important as it makes it possible to assess the internal chronology of these complexes with the new data. Today, on the basis of ${ }^{14} \mathrm{C}$ dates, the Afanasyeva Culture of the Middle Yenisei Region should be attributed to the $30^{\text {th }}-25^{\text {th }} \mathrm{c}$. BC.

Over the past period, the major breakthrough has occurred in the study of chronology of the Okunev Culture. Forty new dates made over the last decade allow a completely new approach. Most of these dates belong to the earliest sites and, as a result, the lower boundary of the culture becomes slightly older and now dates to the second half of the $26^{\text {th }}$ c. BC. The verification of the chronological stages of the culture by ${ }^{14} \mathrm{C}$ dating is crucial. Moreover, the new grounds have been set for determining their absolute age. The most ancient Uibat stage dates to the $26^{\text {th }}-23^{\text {rd }} \mathrm{c}$. BC, Chernov - to the $22^{\text {nd }}-20^{\text {th }} \mathrm{c}$. BC, and the final Razlivskii stage - to the $19^{\text {th }}-18^{\text {th }}$ c. BC.

Far fewer changes have been observed for the chronology of the later sites. Ten new ${ }^{14} \mathrm{C}$ dates for the Andronovo (Fedorov) Culture burials only confirmed the previously established boundaries of $17^{\text {th }}-15^{\text {th }} \mathrm{c}$. BC. Only a small number of new dates were included in the list of determinations for the Late Bronze Age period, which also did not affect its chronological boundaries - the end of the $15^{\text {th }}-9^{\text {th }} c$. BC. The lack of changes is primarily due to a small number of new dates. Further study with the radiocarbon method generally confirmed the composite chronology of the Late Bronze Age sites. Stage I dates to the end of the $15^{\text {th }}-14^{\text {th }} \mathrm{c}$. BC, stage II - to the $13^{\text {th }}-11^{\text {th }} \mathrm{c}$. BC, stage III - to the end of the $11^{\text {th }}-9^{\text {th }}$ c. BC, and the final stage IV - to the $9^{\text {th }}-8^{\text {th }}$ c. BC.

In summary, we need to highlight the necessity of the continuous study of the new radiocarbon determinations. The recent increase of the number of new dates is related to the increase of availability of this natural scientific method. Apart from this, the process of gradual narrowing of confidence intervals is visible. Altogether, this allows continuing the process of detailing of chronological boundaries and dating clearly shorter chronological periods, such as stages of the Okunev Culture.

\section{References}

Alekseev A. Iu., Bokovenko N. A., Vasil'ev S. S., Dergachev V. A., Zaitseva G. I., Kovaliukh N. N., Kuk G., van der Plikht I., Possnert G., Sementsov A. A., Skott E. M., Chugunov K. V. Evraziia v skifskuiu epokhu. Radiouglerodnaia i arkheologicheskaia khronologiia. St. Petersburg, Teza, 2005, 290 p. (In Russian)

Allentoft M.E., Sikora M., Sjögren K.G., Rasmussen S., Rasmussen M., Stenderup J., Damgaard P.B., Schroeder H., Ahlström T., Vinner L., Malaspinas A.-S., Margaryan A., Higham T., Chivall D., Lynnerup N., Harvig L., Baron J., Casa Ph D., Dąbrowski P., Duffy P.R., Ebel A. V., Epimakhov A., Frei K., Furmanek M., Gralak T., Gromov A., Gronkiewicz S., Grupe G., Hajdu T., Jarysz R., Khartanovich V., Khokhlov A., Kiss V., Kolář J., Kriiska A., Lasak I., Longhi C., McGlynn G., 
Merkevicius A., Merkyte I., Metspalu M., Mkrtchyan R., Moiseyev V., Paja L., Pálfi G., Pokutta D., Pospieszny Ł., Price T.D., Saag L., Sablin M., Shishlina N., Smrčka V., Soenov V.I., Szeverényi V., Tóth G., Trifanova S. V., Varul L., Vicze M., Yepiskoposyan L., Zhitenev V., Orlando L., SicheritzPontén T., Brunak S., Nielsen R., Kristiansen K., Willerslev E. Population genomics of Bronse Age Eurasia. Nature, 2015, vol. 522, no. 7555, pp. 167-172.

Bokovenko N. A., Mitiaev P.E. Afanas'evskii mogil’nik Malinovyi Log na Enisee. Afanas'evskii sbornik. Barnaul, 2010, pp. 16-29. (In Russian)

Bokovenko N. A., Legrand S. Das karasukzeitliche Gräberfeld Ancil Con in Chakassien. Eurasia Antiqua, 2000, Bd. 6, Ss. 210-248.

Görsdorf J., Parzinger H., Nagler A, Leontyev N. Neue ${ }^{14}$ C-Datierungen für die Sibirische Steppe und ihre Konsequenzen für die regionale Bronzezeitchronologie. Eurasia Antiqua, 1998, Bd. 4, Ss. 73-80.

Görsdorf J., Parzinger H., Nagler A. New radiocarbon dates of the North Asian steppe zone and its consequences for the chronology. Radiocarbon, 2001, vol. 43 (2B), pp. 1115-1120.

Khokhlov A. A., Solodovnikov K. N., Rykun M. P., Kravchenko G. G., Kitov E. P. Kraniologicheskie dannye k probleme sviazi populiatsii iamnoi i afanas'evskoi kul'tur Evrazii nachal'nogo etapa bronzovogo veka. Vestnik arkheologii, antropologii i etnografii, 2016, no. 3 (34), pp. 86-106. (In Russian)

Lazaretov I.P. K otnositel'noi khronologii afanas'evskoi kul'tury Srednego Eniseia ili khorosho zabytoe staroe. Drevnosti Sibiri i Tsentral'noi Azii, 2017, no. 8 (20), pp. 8-34. (In Russian)

Lazaretov I.P. Okunevskie mogil'niki v doline reki Uibat. Okunevskii sbornik. St. Petersburg, 1997, pp.1964. (In Russian)

Lazaretov I. P. Zakliuchitel'nyi etap epokhi bronzy na Srednem Enisee. Diss. ... kand. philos. nauk. St. Petersburg, 2006. (In Russian)

Lazaretov I. P., Morozov S. V., Poliakov A. V. Novye dannye o manipuliatsiiakh s cherepami v pogrebal'nom obriade okunevskoi kul'tury. Drevnie nekropoli - pogrebal'no-pominal'naia obriadnost', pogrebal'naia arkhitektura i planirovka nekropolei. St. Petersburg, 2018, pp. 51-56. (In Russian)

Lazaretov I. P., Poliakov A.V. Khronologiia i periodizatsiia kompleksov epokhi pozdnei bronzy Iuzhnoi Sibiri. Etnokul'turnye protsessy $v$ Verkhnem Priobe i sopredel'nykh regionakh $v$ kontse epokhi bronzy. Barnaul, 2008, pp. 33-55. (In Russian)

Narasimhan V., Patterson N., Moorjani P., Lazaridis I., Mark L., Mallick S., Rohland N., Bernardos R., Kim A., Nakatsuka N., Olalde I., Coppa A., Mallory J., Moiseyev V., Monge J., Olivieri L., Adamski N., Broomandkhoshbacht N., Candilio F., Cheronet O., Culleton B., Ferry M., Fernandes D., Gamarra B., Gaudio D., Hajdinjak M., Harney E., Harper T., Keating D., Lawson A. M., Michel M., Novak M., Oppenheimer J., Rai N., Sirak K., Slon V., Stewardson K., Zhang Z., Akhatov G., Bagashev A., Baitanayev B., Bonora G., Chikisheva T., Derevianko A., Enshin D., Douka K., Dubova N., Epimakhov A., Freilich S., Fuller D., Goryachev A., Gromov A., Hanks B., Judd M., Kazizov E., Khokhlov A., Kitov E., Kupriyanova E., Kuznetsov P., Luiselli D., Maksudov F., Meiklejohn C., Merrett D., Micheli R., Mochalov O., Muhammed Z., Mustafakulov S., Nayak A., Rykun M., Pettner D., Potts R., Razhev D., Sarno S., Sikhymbaevae K., Slepchenko S., Stepanova N., Svyatko S., Vasilyev S., Vidale M., Voyakin D., Yermolayeva A., Zubova A., Shinde V., Lalueza-Fox C., Meyer M., Anthony D., Boivin N., Thangaraj K., Kennett D., Frachetti M., Pinhasi R., Reich D. The Genomic Formation of South and Central Asia. Science, 2019, vol.365, eaat7487.

Poliakov A. V. Periodizatsiia "klassicheskogo" etapa karasukskoi kul'tury (po materialam pogrebal'nykh pamiatnikov). Diss. ... kand. philos. nauk. St. Petersburg, 2006. (In Russian)

Poliakov A.V. Radiouglerodnye daty afanas'evskoi kul'tury. Afanas'evskii sbornik. Barnaul, 2010, pp. 158171. (In Russian)

Poliakov A.V. Skhema periodizatsii klassicheskogo etapa karasukskoi kul'tury. Stepi Evrazii v drevnosti i srednevekov'e. St. Petersburg, 2002, pp. 209-213. (In Russian)

Poliakov A. V., Svyatko S. V. Radiouglerodnoe datirovanie arkheologicheskikh pamiatnikov neolita - nachala zheleznogo veka Srednego Eniseia: obzor rezul'tatov i novye dannye. Teoriia i praktika arkheologicheskikh issledovanii, 2009, iss. 5, pp. 20-56. (In Russian)

Poliakov A.V., Svyatko S. V., Stepanova N. F. Novye dannye po radiouglerodnoi khronologii pamiatnikov afanas'evskoi kul'tury Altaia. Trudy V (XXI) Vserossiiskogo arkheologicheskogo s"ezda v Barnaule-Belokurikhe, vol.III. Barnaul, 2017, pp. 62-66. 
Poliakov A.V., Svyatko S. V., Stepanova N. F. Problema radiouglerodnoi khronologii afanas'evskoi kul'tury i novye dannye. Fenomeny kultur rannego bronzovogo veka stepnoi i lesostepnoi polosy Evrazii: puti kul'turnogo vzaimodeistviia $v$ V-III tyc. do n.e. Orenburg, 2019, pp. 181-187. (In Russian)

Poliakov A. V., Svyatko S. V., Stepanova N. F. Sovremennoe sostoianie radiouglerodnogo datirovaniia afanas'evskoi i okunevskoi kul'tur. Nauchnoe obozrenie Saiano-Altaia, 2018, no. 1 (21), iss. 5, pp.14-22. (In Russian)

Poliakov A., Svyatko S., Stepanova N. A review of the radiocarbon dates for the Afanasyevo Culture (Central Asia): Shifting towards the "shorter" chronology. Radiocarbon, 2019, vol.61, iss. 1, pp. 243-263. (In Russian)

Poliakov A. V. Radiouglerodnye daty okunevskoi kul'tury. Zapiski IIMK RAN, 2017, no. 16, pp.52-74. (In Russian)

Poliakov A. V. Radiouglerodnye daty pamiatnikov andronovskoi (fedorovskoi) kul'tury na Srednem Enisee. Zapiski IIMK RAN, 2019, no. 20, pp. 163-173. (In Russian)

Savinov D. G. K probleme vydeleniia pozdnego etapa okunevskoi kul'tury. Teoriia i praktika arkheologicheskikh issledovanii, 2005, iss. 1, pp. 28-34. (In Russian)

Svyatko S. V., Poliakov A. V. Novye radiouglerodnye daty pamiatnikov epokhi bronzy — nachala zheleznogo veka Srednego Eniseia. Rol' estestvenno-nauchnykh metodov v arkheologicheskikh issledovaniiakh. Barnaul, 2009, pp. 146-149. (In Russian)

Svyatko S. V., Mallory J. P., Murphy E. M., Poliakov A. V., Reimer P. J., Schulting R. J. New radiocarbon dates and a review of the chronology of prehistoric populations from the Minusinsk basin, Southern Siberia, Russia. Radiocarbon, 2009, vol.51, iss. 1, pp. 243-273. (In Russian)

Vadetskaia E. B. Arkheologicheskie pamiatniki v stepiakh Srednego Eniseia. Leningrad, 1986.

Vadetskaia E. B., Poliakov A.V., Stepanova N.F. Svod pamiatnikov afanas'evskoi kul'tury. Barnaul, Azbuka Publ., 2014, 380 p. (In Russian)

Zaitseva G.I., Timofeev V.I., Sementsov A.A. Radiouglerodnoe datirovanie v IIMK RAN: istoriia, sostoianie, rezul'taty, perspektivy. Rossiiskaia arkheologiia, 1999, no. 3, pp. 5-21. (In Russian)

Статья поступила в редакцию 20 апреля 2020 г. Рекомендована в печать 25 мая 2021 г. Received: April 20, 2020 Accepted: May 25, 2021 